\title{
骨盤内多臓器造影による女性の会陰ヘルニア診断
}

\author{
大腸肛門病センター高野会くるめ病院 \\ 荒木靖三野明俊裕永江隆明 \\ 藤 勇二岩谷泰 江 中川 元 典
}

女性の会陰へルニア（perineal hernia）には levator hernia や，泌尿器生殖器裂孔と 直腸肛門裂孔からへルニアが発生すると考えられる. 今回, 骨盤内多臟器造影を行い, 会陰ヘルニアの解剖学的部位に基づく分類を行い，会陰部脱出（感）との関連性につい て検討した。

会陰部脱出（感）を主訴に当院を受診した46症例（66病変）において骨盤内多臓器造 影検查で levator hernia に分類される直腸後方 S 状結腸瘤を $4.5 \%$, 泌尿器生殖器裂孔 ヘルニアに分類される腔後方ヘルニアを $19.7 \%$, 膀胱脱 $3.0 \%$, pelvic quasi hernia 1.5 $\%$ ，直腸肛門裂孔へルニアに分類される完全直腸脱を $53.0 \%$ ，完全直腸脱の直腸内にへ ルニア囊を有する massive rectal prolapse を10.6\%，不完全直腸脱を $4.5 \%$ に併発して いた.

会陰ヘルニアの治療方針において骨盤内多臟器造影検查は会陰へルニアの機能的，形 態的診断には欠かせない検査方法であることが示唆された。

索引用語：会陰ヘルニア，直腸脱，骨盤内多臓器造影検查

\section{緒 言}

女性における会陰部のヘルニアは直腸瘤, 小腸瘤, 膀胱脱など脱出臓器を名称とする分類が臨床的に用い られ，ヘルニアの解剖学的部位に基づく分類が用いら れておらず，治療方法も明確ではない。かかる観点か ら，会陰部のへルニアを解剖学的部位に基づいた分類 を行い，会陰部脱出感との関連を検討する．会陰部の ヘルニアは骨盤ヘルニア（pelvic hernia）と会陰ヘル ニア (perineal hernia) の二つに大別される．前者に は閉鎖孔へルニア，坐骨ヘルニアがあり，後者には挙 肛筋群において levator funnel が原因となって起こる levator hernia がある。また，陰部と生殖裂孔からな る泌尿器生殖器裂孔（urogenital hiatus）と直腸肛門 が連なる直腸肛門裂孔 (anorectal hiatus) のそれぞれ の部位からへルニアが発生すると考えられ，天野の会 陰へルニアの分類 ${ }^{1}$ をとに骨盤内多藏器造影を行い 臨床的に分類し，その意義について考察した。

\section{7年 1 月 30 日受付 2007 年10月 22 日採用}

\section{〈所属施設住所〉}

干839-0865 久留米市新合川 $2-2-18$

\section{対象と方法}

2004 年 1 月から 2006 年 3 月までの 2 年間に会陰部脱 出（感）を主訴に当院を受診した女性，46症例（66病 変). 平均年齢75.7歳 (21 96歳).

検查 2 時間前にバリウムを服用し，前もつて小腸を 造影する.さらに $60 \%$ ウログラフィン $40 \mathrm{ml}$ を用いて逆 行性膀胱造影を行い, 臸内にはウログラフィンを浸透 したガーゼを挿入，直腸内にペースト状バリウム 150 $\mathrm{ml}$ を注入した. 透視台に設置された便器に座り, 安静 時, 収縮時, 怒責時の側面像を撮影した（図 1$)^{2) ~ 4) . ~}$ 怒責時のレントゲン写真から診断し，表 1 のように会 陰へルニア分類を行った。すなわち，挙肛筋群全体が 下垂し，骨盤内臓器がすべて下垂するものを挙肛筋へ ルニア (levator hernia), さらに子宮の前方から脱出 する性器脱を泌尿器生殖器裂孔のなかでも前腹膜へル ニア（anterior peritoneal hernia）に区分した。さら に，子宮後方の性器脱には腹膜外で主に子宮が脱出す る extraperitoneal vaginal hernia, ダグラス窩腹膜が 下垂し，小腸瘤や $\mathrm{S}$ 状結腸瘤を形成する peritoneal vaginal hernia, 子宮が反転し性器脱をきたす pelvic quasi hernia と診断した。また，直腸肛門裂孔の内， 


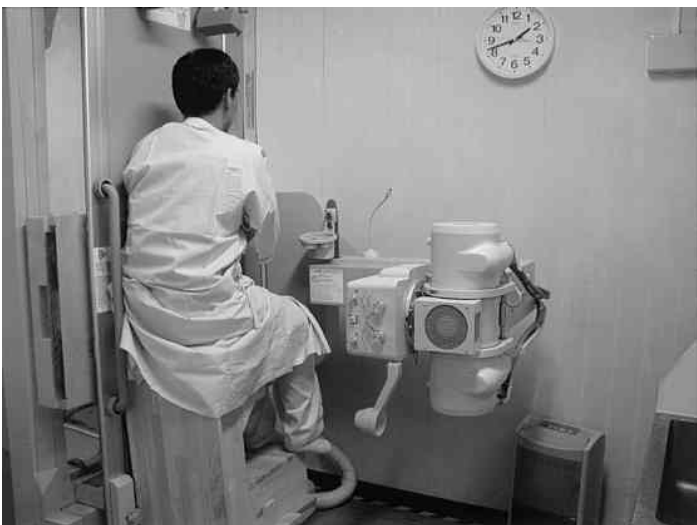

図 1 骨盤内多臓器造影検査

\section{表 1 会陰ヘルニア分類}

1) Levator hiatus

2) Urogenital hiatus

A. Anterior peritoneal hernia

B. Genital hernia

a. Extraperitoneal vaginal hernia

b. Peritoneal vaginal hernia

c. Pelvic quasihernia

3) Anorectal hiatus

A. Internal rectal prolapse

B. Complete rectal prolapse

C. Massive rectal prolapse

直腸重積を認めるが肛門からの直腸脱出を伴わないも のを不完全直腸脱と診断し，直腸が脱出し，脱出した 直腸内にヘルニア囊を認めないものを完全直腸脱の単 純型 (simple type), 直腸内にヘルニア囊を有するも のを massive type と診断し, そのへルニア囊内に陥入 する臟器によって, 小腸瘤, S 状結腸瘤と診断した(図 $2,3)$.

\section{結 果}

会陰部脱出 (感)を主訴に当院を受診した 46 症例 (66 病変）において levator hernia に分類される $\mathrm{S}$ 状結腸 瘤を $4.5 \%$, 泌尿器生殖器裂孔のなかでも前腹膜へルニ ア (anterior peritoneal hernia）による膀胱脱 $3.0 \%$ ， 子宮後方の腹膜外で主に子宮が脱出する extraperitoneal vaginal hernia 3.0\%，ダグラス窩腹膜が下垂 し，小腸瘤や $\mathrm{S}$ 状結腸瘤を形成する peritoneal vaginal hernia が19.7\%，子宮が反転し性器脱をきたす pelvic quasi hernia $1.5 \%$ であり, 直腸肛門裂孔に分 類される完全直腸脱のうち単純型 $53.0 \%$ ，直腸内にへ

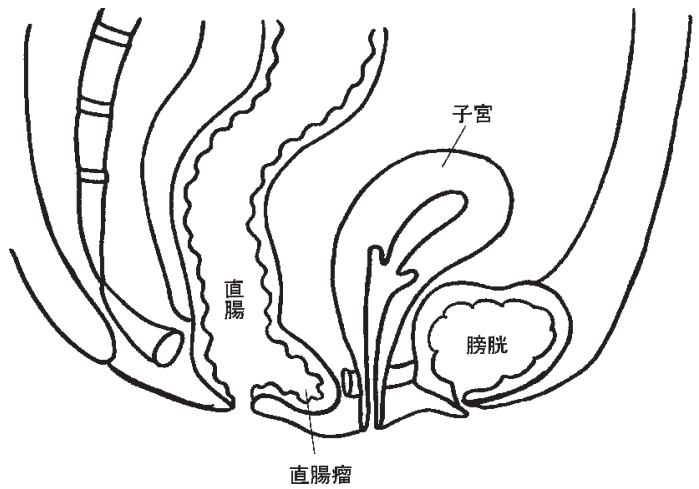

図 2 会陰ヘルニアのシェーマ

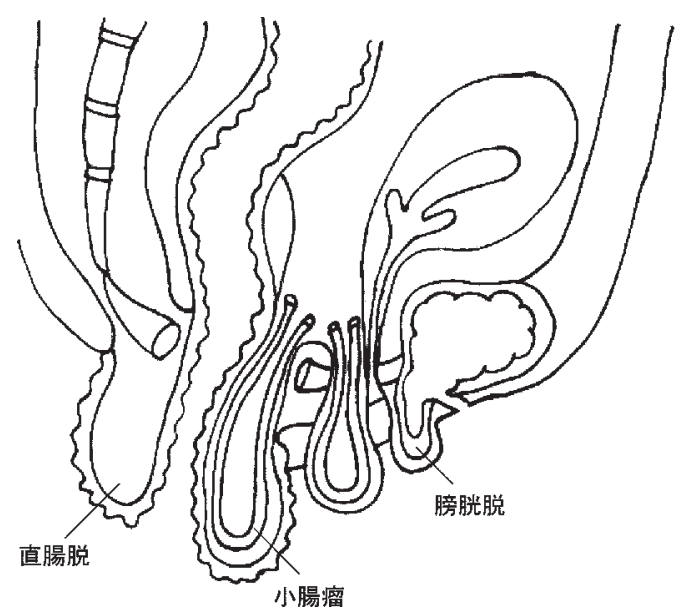

図 3 会陰ヘルニアのシェーマ

ルニア囊を有する massive rectal prolapse $10.6 \%$, 不完全直腸脱を $4.5 \%$ に認めた（図 4 ）.

症例 $1: 58$ 歳, 女性. 肛門部脱出を主訴に来院し, 骨 盤内多藏器造影（図５）では，骨盤底には異常を認め ないが, 直腸が重積し, 肛門からの脱出 (complete rectal prolapse）が認められた。

症例 $2 ： 83$ 歳，女性. 会陰部下垂感を主訴に来院し た。骨盤内多臟器造影（図 6 ) では，肛門外に直腸の 重積，脱出を伴い，さらに重積した直腸に子宮が入り 込んだ massive rectal prolapse を認めた。

症例 $3: 78$ 歳，女性. 会陰部脱出を主訴に受診した。 骨盤内多藏器造影 (図 7 ) では, 子宮後方の腹膜外で 子宮が脱出する extraperitoneal vaginal hernia とダ グラス窩腹膜が下垂し, S 状結腸瘤を形成した peritoneal vaginal hernia を認める.さらに, 重積, 脱出 


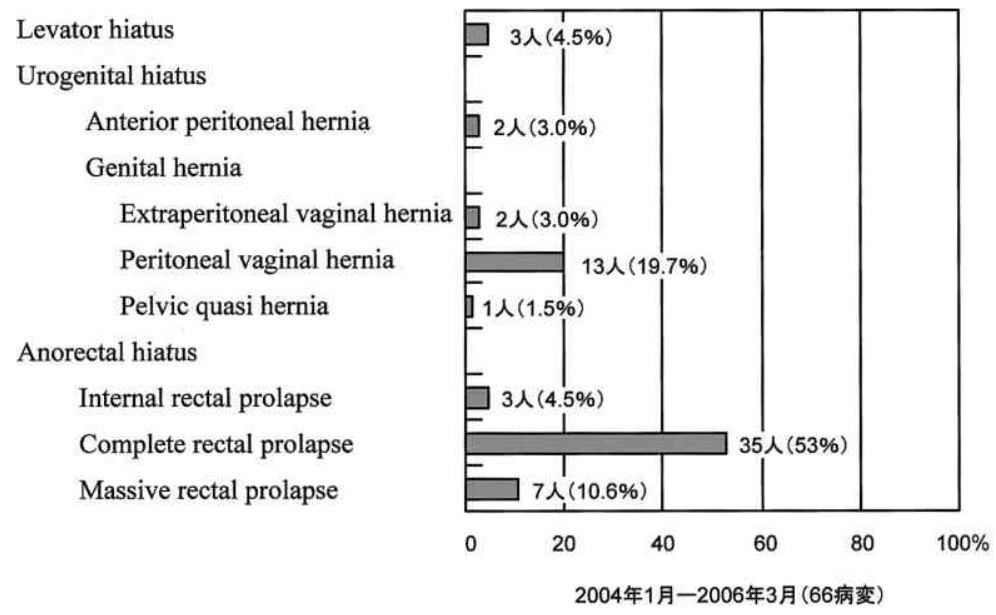

図 4 会陰ヘルニアの分類と頻度

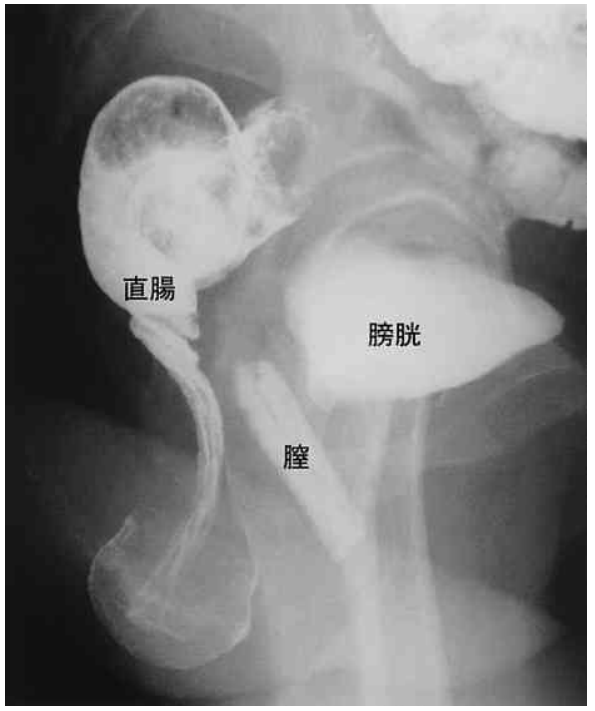

図 5 症例 1 の骨盤内多臓器造影検査所見：直 腸が重積し，肛門からの脱出（完全直腸脱）が 認められる。

した直腸内に小腸が入り込んだ massive rectal prolapse を認める.

症例 4：82歳，女性. 会陰部下垂感を主訴に受診し た。骨盤内多藏器造影(図 8 ) では, 子宮後部から S 状 結腸の脱出が,臸壁に被われている posterior perineal hernia が認められた。

症例 5：85歳, 女性. 会陰部脱出を訴え, 受診した。 骨盤内多臓器造影（図９）では，直腸が重積し，肛門 からの脱出を認める完全直腸脱の単純型と，ダグラス

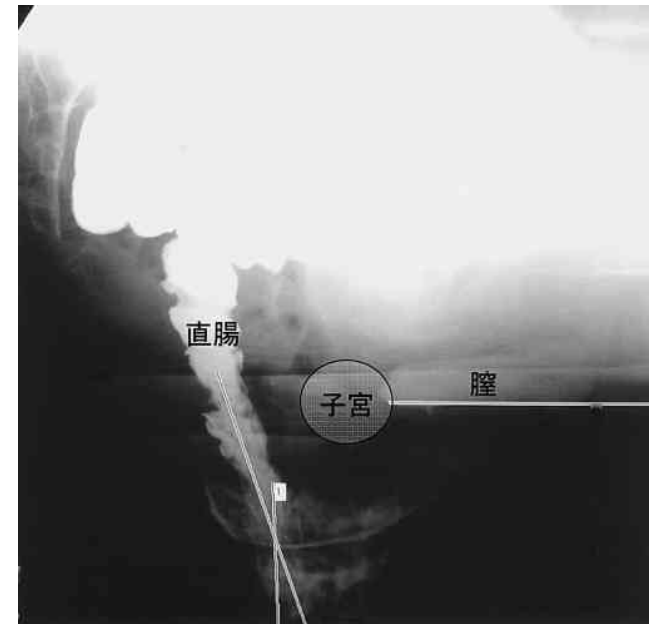

図 6 症例 2 の骨盤内多藏器造影検査所見：重積脱 出した直腸内に子宮が陥入している.

窩腹膜が下垂し，小腸瘤を形成した peritoneal vaginal hernia を認めた。

考 察

1885年 Thomas は vaginal hernia cystocele, rectocele, vaginal enterocele, pudendal enterocele, perineal enteroceleの 5 つに分類し ${ }^{5)}$ ，さらに1940年 Wilensky らは extravaginal hernia (urethrocele, cystocele, rectocele), peritoneal vaginal hernia (anterior, posterior, lateral anterior, lateral posterior, postoperative), perineal hernia, hedrocele, pudendal hernia, pelvic quasi hernia と現在の分類 


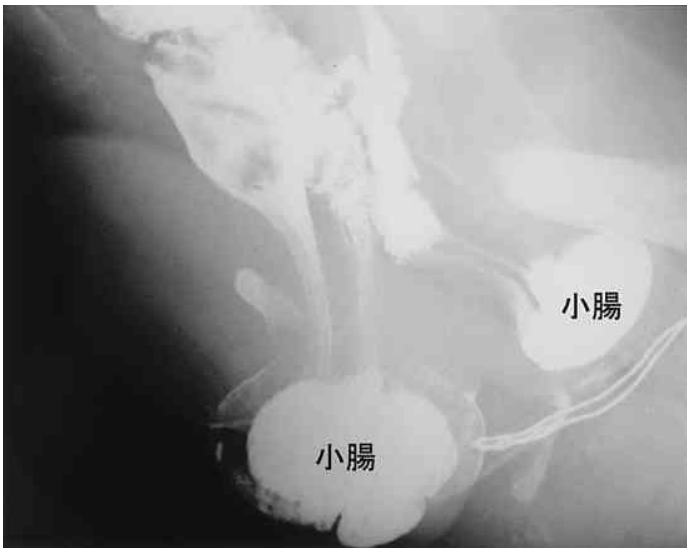

図 7 症例 3 の骨盤内多藏器造影検査所見：posterior vaginal hernia 内に小腸瘤, さらに重積脱出した直腸 内にも小腸瘤を認める。

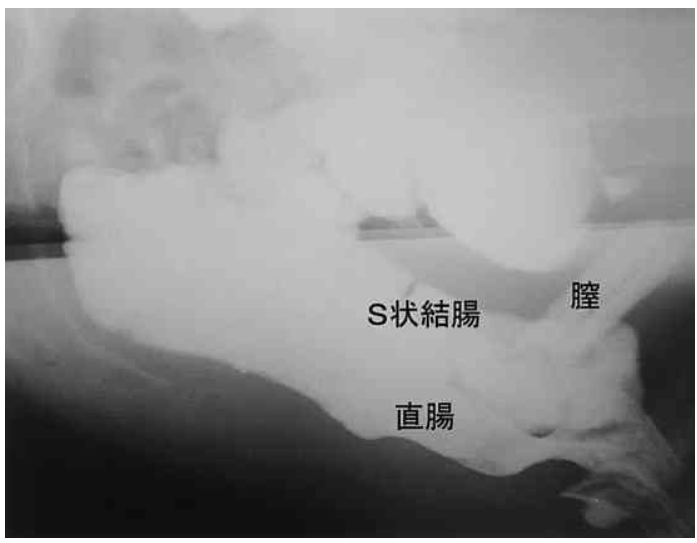

図 8 症例 4 の骨盤内多臓器造影検査所見：posterior vaginal hernia 内に S 状結腸瘤を認める。

\section{に近い形に分類している ${ }^{6)}$.}

会陰部のヘルニアは骨盤ヘルニア（pelvic hernia） と会陰ヘルニア（perineal hernia）の二つに大別され る.前者には閉鎖孔へルニア，坐骨へルニアがあり， 後者には挙肛筋群において levator hiatus（挙肛筋裂 孔）が原因となって起こるもの，陰部と生殖裂孔から なる urogenital hiatus (泌尿器生殖器裂孔)，そして anorectal hiatus（直腸肛門裂孔）からなり，それぞれ の部位からへルニアが発生すると考えられる.さらに， urogenital hiatus genital hernia に分けられ，とくに genital hernia は extraperitoneal vaginal hernia, peritoneal vaginal hernia, pelvic quasiherniaに分類される。また, anor-

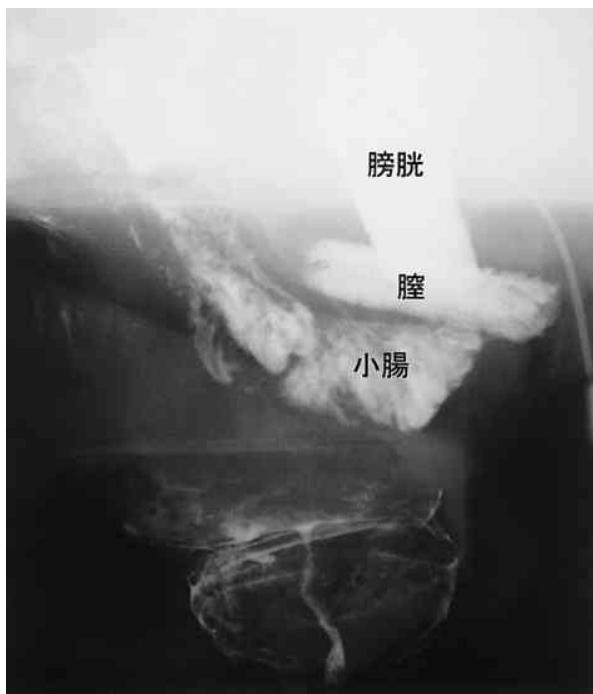

図 9 症例 5 の骨盤内多臓器造影検査所見：重 積脱出した直腸内に小腸砶を認める。

ectal hiatus は肛門から直腸の脱出がない internal rectal prolapse (不完全直腸脱), 直腸が脱出する complete rectal prolapse (完全直腸脱), 脱出した直腸内 に腹膜外ヘルニアを有する massive rectal prolapse の 3 つに分類される。そして，ヘルニア囊内に陥入す る臓器によって，小腸瘤，結腸瘤などが診断される。

骨盤内臟器の下垂を調べる方法として，骨盤内多臟 器造影検査の他に簡便な MRI 検査があるが，両者を 比較すると，前者の正診率は直腸瘤 $66 \%$, 膀胱脱 $70 \%$, 子宮脱 $42 \%$, 小腸瘤 $87 \%$ と報告されている778).さらに, 骨盤内多臟器造影検査の方が不完全直腸脱，S 状結腸 瘤の診断がより正確であると報告されている

MRI 検査は簡便で, 低侵襲的な検査方法であるが, 側臥位で検查をするために，座位で怒責し撮影を行う 骨盤内多臓器造影検査と比較して，正診率が低くなる ことはやむを得ない.

しかしながら, 骨盤内多臓器造影検査は手技の煩雑 さ，患者の差恥心など考慮すべき点がいくつか挙げら れるが, 骨盤内臟器の安静時, 収縮時, 怒責時の形態 観察のみならず，膀胱造影によって cystometory や経 時的な排便排尿量の測定 ${ }^{10)} に も$ 応用される.

今回の検討では，会陰へルニアとして levator hernia に分類される直腸後方 S 状結腸瘤 $4.5 \%$, 泌尿器生 殖器裂孔に分類される臸後方へルニア $19.7 \%$, 膀胱脱 $3.0 \%$ ，直腸肛門裂孔に分類される (単純) 完全直腸脱 $53.0 \%$ ，massive rectal prolapse $10.6 \%$ ，不完全直腸 
脱 $4.5 \%$ の内訳で，その内，直腸脱の治療において骨盤 ヘルニアの併発病変が $43 \%$ であた。この他にも，同 様な方法で肛門の不定愁訴を訴える患者 73 名に排便造 影検査を行い，29\%に直腸瘤，18\%に小腸瘤，5\%に $\mathrm{S}$ 状結腸瘤を認めた報告 ${ }^{11}$ や，直腸脱55名の女性にビ デオ排便造影を行い，52\%に骨盤底筋群に異常を認め た ${ }^{12)}$ 報告もあり，著者らの結果と同じような頻度で骨 盤ヘルニアの併発疾患が認められた。

これらのことから, 直腸脱患者において術前に骨盤 内併発疾患を見落とさないためにも骨盤内多藏器造影 検查を行うことは重要であり, また直腸脱の治療方法 を予測でき, 直腸脱の術後再発予防や患者の愁訴を軽 減できる可能性が示唆された。

外見上は完全直腸脱として診断される症例の中に massive rectal prolapse として extraperitoneal vaginal hernia を有する症例が33\%存在する.このことは, ガント三輪術や Delorme 術, 直腸固定術などによる直 腸脱治療において extraperitoneal vaginal hernia が 治療されないことが, 術後の再発例に直腸前方の粘膜 脱が多いことに起因すると推測される。

\section{結 語}

多臟器造影検查は会陰へルニアの形態的診断には欠 かせない検查方法であり，会陰へルニアの治療方針決 定に重要であることが示唆された.

\section{文献}

1) 天野信一：Posterior vaginal hernia 91 例. 日 本大腸肛門病会誌 $55 ： 108-113 ， 2002$

2) Takano M, Hamada A:Evaluation of pelvic descent disorders by dynamic contrast roentgenography. Dis Colon Rectum 43: S6-11, 2000

3) Altringer WE, Saclarides TJ, Dominguez JM, et al:Four-contrast defecography : pelvic "floor-oscopy". Dis Colon Rectum 38:695699, 1995

4) Bertschinger KM, Hetzer FH, Roos JE, et al: Dynamic MR imaging of the pelvic floor performed with patient sitting in an open-magnet unit versus with patient supine in a closedmagnet unit. Radiology 223 : 501-508, 2002

5) Thomas TG:Vulvar and vaginal Enterocele. NY Med J 42: 705-711, 1885

6) Wilensky AO, Kaufman PA: Vaginal hernia. Am J Surg 49:31-41, 1940

7) Kelvin FM, Maglinte DD, Hale DS, et al: Female pelvic organ prolapse : a comparison of triphasic dynamic MR imaging and triphasic fluoroscopic cystocolpoproctography. AJR Am J Roentgenol $174:$ 81-88, 2000

8) Devel B, Vulierme MP, Poilpot S, et al: Imaging pelvic floor prolapse. Gynecol Obstet Biol Reprod 32:22-29, 2003

9) Kaufman HS, Buller JL, Thompson JR, et al: Dynamic pelvic magnetic resonance imaging and cystocolpoproctography alter surgical management of pelvic floor disorders. Dis Colon Rectum $44:$ 1575-1583, 2001

10) Shafik A, Khalid AM : Fecoflowmetry in fecal incontinence. Eur Surg Res 24 :61-68, 1992

11) Kelvin FM, Maglinte DD, Hornback JA, et al: Pelvic prolapse:assessment with evacuation proctography. Radiology $186:$ 907, 1993

12) Peter WA, Smith $M R$, Drescher $C W$ : Rectal prolapse in women with other defects of pelvic floor support. Am J Obstet Gynecol 184 : 1488 $-1494,2001$ 


\title{
DYNAMIC CYSTOCOLPOPROCTOGRAPHY FOR THE FEMALE PERINEAL HERNIA
}

\author{
Yasumi ARAKI, Toshihiro NOAKE, Takaaki NAGAE, \\ Yuji TOU, Yasue IWATANI and Motonori NAKAGAWA \\ Kurume Coloproctology Center
}

The aim of this study is to assess the contribution of dynamic cystocolpoproctography for the evaluation of female pelvic organ prolapse. Perineal hernia was classified levator hernia, urogenital hernia and anorectal hernia, and urogenital hernia was divided to anterior peritoneal hernia and genital hernia. Anorectal hiatus hernia was divided to internal rectal prolapse, complete rectal prolapse and massive rectal prolapse. The cystocolpoproctography was retrospectively analyzed in 46 consecutive patients. Sigmoidecele classified as levator hernia was detected in $4.5 \%$ of the patients, postvaginal hernia in $19.7 \%$, cystocele in $3.0 \%$, complete rectal prolapse in $53.0 \%$, massive rectal prolapse in $10.6 \%$, and incomplete rectal prolapse in $4.5 \%$ of the patients on cystocolpoproctography.

Perineal hernia can include a combination of cystocele, rectocele, uterine prolapse, enterocele and rectal proplapse. Accurate diagnosis of the coexisting abnormalities is essential in planning reconstructive procedures so that the risks of recurrence and reoperation can be minimized.

In conclusion, dynamic cystocolpoproctography provides direct visualization and quantification of female pelvic organ prolapse, and information that usually can only be inferred by physical examination. 